\title{
THE ETHICAL AUTHORITY OF THE OLD TESTAMENT: A SURVEY OF APPROACHES. PART I 1
}

\section{Christopher J.H. Wright}

The question of what authority the scriptures of the Hebrew Bible have for Christians and how they should be used for ethics is, and always has been, difficult and divisive. The purpose of Part I of this article is primarily to survey some approaches to the problem, both ancient and modern, examining assumptions and methods. In Part II it is proposed to evaluate some contemporary evangelical attempts to answer these questions: viz. dispensationalism, theonomism, messianic Judaism and relationism of the Jubilee Centre, Cambridge and to suggest ways of furthering the discussion on the ethical authority of the Old Testament. ${ }^{2}$

\section{The Early Church}

In a brief but stimulating article, Richard Longenecker suggested that there were three major positions or traditions of biblical hermeneutics (specifically on handling the Old Testament) in the early centuries and that these three approaches have continued to be influential all through Christian history. ${ }^{3}$ His classification provides a useful starting point and grid for our survey.

\section{Marcion}

No writings of Marcion have survived so he is known only through those who opposed him, especially Irenaeus and Tertullian. Writing in the mid 2nd century AD, his starting point was Galatians, which he understood as directed against Judaism and all things Jewish. The revelation of God in Jesus

\footnotetext{
${ }^{1}$ This paper is based on the 1991 Annual Tyndale Ethics Lecture and the 1991 Griffiths Thomas Lectures, Wycliffe Hall, Oxford.

2Part II will appear in Tyndale Bulletin 43.2 (November 1992).

${ }^{3}$ R.N. Longenecker, 'Three Ways of Understanding Relationships between the Testaments: Historically and Today', in G.F. Hawthorne and $O$. Betz (edd.), Tradition and Interpretation in the New Testament: Essays in Honor of E. Earle Ellis for His Sixtieth Birthday (Eerdmans \& Mohr, 1987) 22-32.
} 
was totally different from the work of the Jewish creator God. He thus saw a radical discontinuity between the Jewish scriptures and the Christian New Testament. The Hebrew Bible had no relevance or authority for Christians and should be regarded as having no place in Christian scripture-along with several parts of the New Testament which he judged to be seriously infected with Jewish concerns. Not surprisingly, any ethical authority of the Old Testament for Christians is rejected a priori. Marcion's radical rejection of the Hebrew Scriptures was itself rejected by the church. His attack, however, was indirectly one of the factors which led to the clarification and defining of the canon of Christian scripture, with the Old Testament firmly included.

\section{The Alexandrian fathers}

Christian scholarship at Alexandria flourished from the late 2nd to mid 3rd century. The most notable figures there were Clement and Origen, Origen being the more prolific and influential. Origen distinguished between the 'letter' and the 'spirit' of the Old Testament, with priority given to the spiritual meaning and purpose of the text. He did not deny the historical and literal meaning of the Old Testament, but argued that often the literal sense of a story or command was simply impossible and concluded that the Spirit must have intended the reader to look for a hidden spiritual meaning. The Word could use historical stories to teach spiritual truths, but could also weave into the narrative things which did not happen, or into the law things which could not be obeyed. The reader is thereby forced to seek the higher sense worthy of God.4

Origen also made a distinction between two parts of the law-the ceremonial and the moral (though in fact in his commentary on Romans he listed six ways in which Paul talks about law!). The first part came to an end in Christ, but the second part was retained and amplified by Christ. This distinction, subsequently expanded by the identification of a third category, namely Israel's civil or judicial law, has remained as a major hermeneutical framework for handling Old Testament law right down to the present day.

${ }^{4}$ See K. Froehlich, Biblical Interpretation in the Early Church (Philadelphia, Fortress 1984) 62-4. 
Since the main characteristic of the Alexandrian school was the belief that there was a spiritual meaning already there, intentionally hidden in the text of the Old Testament by the Spirit, they had to devise a method for getting at this hidden meaning and expounding it. The allegorical method of exegesis and interpretation was their solution. Though it has become that for which Alexandria is most famous, it should be remembered that this allegorical method was essentially just a tool, and was later discarded or modified by the heirs of their tradition. The more important legacy of Alexandria in relation to Old Testament hermeneutics was the presupposition of continuity and harmony between the testaments. The Hebrew scriptures, since they had come from the same Spirit who had inspired the New Testament, must also have Christian spiritual significance. This led to a fairly static conception of the Bible, with little weight given to historical development between the testaments.

\section{The Antiochene fathers}

The rival school of Antioch flourished in the 4th and 5th centuries, and includes such names as Chrysostom, Theodore of Mopsuestia, Theodoret and Diodore of Tarsus in its broad tradition.

Whereas Alexandria subordinated the literal, historical sense of the Old Testament to a higher, moral and spiritual sense (the allegoria), Antioch gave priority to history, and looked for higher principles only secondarily. They used the term theoria or anagoge for such secondary principles. They strongly and vociferously rejected the allegorical methods of Alexandria, and also questioned the two-fold division of the law that stemmed from there

Chrysostom argued that a whole new dynamic had entered the world with the arrival of the gospel in Christ. In the light of that, he did not accept that the Old Testament law had ongoing moral authority for Christians. Even things which had been allowed by the law in the Old Testament could be rejected by Christians because of the newness of life in Christ. He applied this argument to slavery5-being one of the earliest to suggest that although the Old Testament allowed it,

${ }^{5}$ Longenecker, op. cit, 27. 
that did not of itself justify the practice for Christians who must take Galatians 3:28 into consideration.

Diodore of Tarsus, in his commentary on the Psalms, however, did see the ethical value of the Old Testament, provided it is carefully grounded in historical reality and a literal reading of the text. He refused all allegory. ${ }^{6}$ Theodore of Mopsuestia, in his commentary on Galatians emphasises the two covenants, through Moses and through Christ and sets up a very clear law-gospel contrast.7

The Antiochene school thus emphasized the historical development within the Scriptures and the importance of redemptive fulfilment of the Old Testament in the New. This led to a less static and more dynamic approach to biblical authority, in which Old Testament perspectives could be set aside in the light of the 'new thing' of the incarnation and kingdom of God in Christ. Both Alexandria and Antioch believed in the continuity between the Testaments, but whereas Alexandria saw sameness and made the Old Testament say Christian things, Antioch saw development and allowed the New Testament to override the Old where necessary.

Longenecker suggests, then, that these three attitudes and approaches to the Old Testament have surfaced in different traditions in the church ever since. Though officially rejected by the church, the ghost of Marcion has haunted the hermeneutical house down through the ages, making its appearance in the antinomian tendencies of the radical wing of the reformation, the ahistorical existentialism of Bultmann and kindred spirits, and (for very different theological reasons) in modern Dispensationalism. And those are only the theological movements. Many churches are in practice Marcionite in their abysmal neglect of the scriptures that Jesus himself used, refusing to read them in worship even when lectionary provision is made for it. Small wonder there is such confusion over whether and how the Old Testament has anything ethical to contribute to the Christian's resources for practical living.

The influence of Alexandria lives on in Calvin and the Reformed tradition-not in its allegorical treatment of the Hebrew Bible, which Calvin definitely rejected in favour of a careful historico-grammatical exegesis, but in the commitment

6Froehlich, op. cit., 82.

7Idem, op. cit., $98 \mathrm{ff}$. 
to the unity and continuity of the Testaments such that the Old Testament is read as unquestionably Christian scripture to be interpreted and obeyed in the light of Christ. Its influence can be seen in the Puritans' emphasis on the 'third (moral) use' of the law in the Christian's life. A static kind of unity is pushed to its ethical extreme in the Theonomist movement which asserts that the moral authority of the Old Testament applies with as much force as the law did for Israel, since it is God's law for all time for all humanity. Whereas, however, the Alexandrians made Hebrew law relevant by allegorizing it, theonomists wish to make it relevant by literal application as far as possible.

\section{The Reformation Era}

The Antiochene antipathy to allegory surfaced again in Luther's bold rejection of mediaeval scholastic theology. Luther was also more Antiochene than Calvin in allowing the new wine of the Gospel to dispense with the old wineskins of the Old Testament wherever he sensed a conflict. Where Calvin sought consistency and harmony, Luther was content with a very free and sometimes inconsistent handling of the Old Testament ethically, which arose from his dynamic and ebullient glorying in the primacy of the gospel as over against the law. As for modern examples of the Antiochene spirit, I think I would point to the heirs of the radical reformation, such as those Mennonites who are concerned and active in social issues. They stress a radical discipleship and have a strongly New Testament, messianic orientation in both theology and ethic, while emphasizing the importance of the distinctiveness of the people of God, which is a value most strongly inculcated in the Hebrew scriptures.

\section{Luther}

Martin Luther, as a biblical expositor, inherited the mediaeval tools of exegesis, which included the allegorical method among others that had been developed in the Western church, particularly in North Africa. The early editions of his Galatians commentary show that Alexandrian influence. However, he came to reject entirely (in principle, if not always consistently in practice) the allegorical method, and swung to a much more Antiochene approach-theologically as well as exegetically. This, of course, was directly related to his own experiential re-discovery of the New Testament gospel. The 
tremendous experience of liberation by the gospel from the burdens of conscience which he felt were imposed upon him by the law and wrath of God led him to a fundamentally Christocentric and gospel-centred approach to everything, including biblical hermeneutics. This entailed a dynamic, historically differentiated, use of the Old Testament, which never relinquished it as essential to the scripture and the Christian faith, but certainly subordinated it to the New Testament and his own understanding of grace and salvation. This led to a not always consistent use of the Old Testament. At times he can teach certain duties from Old Testament laws and stories. At other times he can urge Christians to be free from certain scruples (e.g. in relation to monastic vows) precisely because they (vows) are in the Old Testament, and Christians need not behave like Jews!

Luther saw the law as having had a civil use; like a hedge, it functioned as a political restraint upon human sin in Israelite society. He also saw its spiritual use; like a mirror, it exposes sin and thus drives us in terror and condemnation to repentance and the gospel. This second use is its primary purpose as far as Christians are concerned. There is debate over whether Luther ever accepted a 'third use' of the law-namely as a moral guide for Christian living now, with ethical authority over believers. It seems that he rejected such moral authority for the law, in the sense of Christians being bound to obey it. And yet, in practice, he made extensive use of the Old Testament in his catechisms when dealing with the requirements of Christian behaviour. Much of his teaching there is based on the Decalogue. He 'de-judaises' the commandments and freely reinterprets them in Christian terms, but the assumption is clearly that the ten commandments still function authoritatively in guiding Christian behaviour, even though Luther insists that the Christian is not bound-even by the

${ }^{8}$ See, An Answer to Several Questions on Monastic vows (1526) in Luther's Works, J. Pelikan and H.T. Lehman (edd.), vol. 46 (Philadelphia, 1958)) 146. A very helpful discussion of this feature of Luther, with illustrations and full bibliographical detail, is provided by D.F. Wright, 'The Ethical Use of the Old Testament in Luther and Calvin: A Comparison', SJT 36 (1983) 463-85. See also, G.O. Forde, 'Law and gospel in Luther's hermeneutic', Interpretation 37 (1983) 240-52; D.G. Bloesch, Freedom for Obedience: Evangelical Ethics in Contemporary Times (San Francisco, Harper \& Row 1987) chs 7-8. 
Decalogue. So when it comes to the grounds for finding moral authority in Old Testament law, Luther locates it in natural law. That is, at those points where the Christian is bound by moral authority in the law, it is not by the law qua given by Moses, but by the law as simply reflecting the wider moral will of God in creation.

Fundamentally, however, the law precedes and stands in final contrast with the gospel (as remains the case for Lutheran theology and ethics ever since). The Antiochene model is there; the new events of salvation history in Christ override and supersede all that went before. Thus Luther can be very free in handling not only the laws but also the narratives of the Old Testament. He can engage in curious defence of the morally questionable actions of great heroes of the Old Testament, if he can show that they were acting out of faith in God's promise. In that sense, grace covers a multitude of sins in more ways than one.

\section{Calvin}

Calvin represents a swing of the pendulum towards a more Alexandrian approach to the Old Testament, not in the sense of allegorical exegesis (which Calvin renounced as much as Luther), but in seeing the unity and continuity of the testaments. Calvin affirmed a single covenant of saving grace-the Abrahamic promise-running throughout the Bible, and thus saw the gospel in the Old Testament and made great efforts to display a greater harmony and consistency between the law and the gospel.

Calvin took very seriously Christ's affirmation of the continuing validity of the law and the prophets (Mt. 5:17ff.), so he not only accepted the 'third use' of the law, but regarded it as in fact the most important. The law functions as a practical guide for Christian conduct, to shape and prepare us for good works in response to saving grace. So, whereas Luther, though he was aware of the threefold use of the law, affirmed that the principle use was the second (i.e. to accuse and condemn and terrify us so that we are driven to Christ), Calvin emphasised the third use.

The third and principal use (of the moral law), which pertains more closely to the proper purpose of the law, finds its place among believers in whose hearts the Spirit of God already lives and reigns. . .Here is the best instrument for (believers) to learn more 
thoroughly each day the nature of the Lord's will to which they aspire, and to confirm them in the understanding of it. . .And because we need not only teaching but also exhortation, the servant of God will also avail himself of this benefit of the law: by frequent meditation upon it to be aroused to obedience, be strengthened in it and be drawn back from the slippery path of transgression.9

The law, in fact, provided 'a perfect pattern of righteousness', which applied in all ages, not just to Israelites. Its historical and contextual particularity was of course to be observed, but that did not destroy its relevance to the people of God of later ages. Even Christ did not add to the law, but rather 'he only restored it to its integrity'.10

With this more positive perspective, Calvin argues that the way to derive benefit from the law (and he is principally expounding the Decalogue) is to look for the purpose of each commandment. He constantly seeks a positive use, somewhat in the same way that Jesus often went to the heart of a matter by seeing the point of a law-why it was given and for whose benefit. Likewise Calvin regards it as legitimate to expand the force of the literal words themselves by presupposing that any law prohibits the opposite of what it commands, or commands the opposite of what it prohibits.

One can detect, therefore, a difference between Luther's and Calvin's handling of the law which is almost as much psychological or intuitive, as theological. Whereas Luther often sees what the law prohibits, in order to emphasise its role as a 'killer' from which one must flee to the grace of the gospel, Calvin looks for what the law promotes, using it as a model or primer which he applies to all kinds of issues of Christian living in the world of his day. When either of these approaches (both of which can claim New Testament precedent) are taken to extremes they can, of course, become unbalanced in opposite ways. Thus the danger of Lutheranism is a slide into practical Marcionism or antinomianism, while the danger of Calvinism has always been a slide into legalism. But neither of these extremes can be charged against Luther or Calvin themselves.

In The Institutes Calvin is mainly expounding the Decalogue. However, in his Commentary on a Harmony of

$9 \mathrm{~J}$. Calvin, Institutes 2:7:12.

10Institutes 2:7:13, 2:8:7. 
the Last Four Books of Moses he comments not only on the ten commandments themselves, but on all the other laws which he arranges in relation to their connection with the ten commandments. He makes a further distinction in these latter laws between 'Exposition'-i.e. laws which simply clarify or apply the main thrust of the Decalogue commandment, and therefore belong to the essence of the law and share the continuing moral validity of the Decalogue; and 'Political Supplements'-i.e. civil or ceremonial provisions that were applicable to Israel. This last category of laws need not be imposed in the laws of other societies, so long as the basic purpose of the Decalogue is preserved. Thus, for example, in his handling of the eighth commandment (against stealing), he includes in the 'Exposition': prompt payment of wages (Lv. 19:11,13, Dt. 24:14f., 25:4); care and impartiality for aliens (Ex. 22:21-24, Lv. 19:33f., Dt. 10:17-19); honesty in weights and measures (Lv. 19:35f., Dt. 25:13-16); no removal of boundary markers (Dt. 19:14); duties in respect of pledges for loans (Ex. 22:26-27, Dt. 24:6, 10-13, 17-18); laws against taking interest (Ex. 22:25, Lv. 25:35-38, Dt. 23:19f.); recovery of lost possessions (Ex. 23:4, Dt. 22:1-3); restitution for theft ( $\mathrm{Nu}$. 5:5-7); denunciation of bribery and corruption (Ex. 23:8, Lv. 19:15, Dt. 16:19f.); prohibition on partiality, for or against the poor (Ex. 23:3,6).

He then includes the following laws in the category of 'Political Supplements': gleanings for the poor (Lv. 19:9f., 23:22, Dt. 24:19-22); the sabbatical year (Ex. 21:1-6, Dt. 15:118); the jubilee and redemption regulations (Lv. 25); ban on destroying fruit trees in war (Dt. 20:19f.); exemptions from military service for certain categories of people (Dt. 20:5-8); the levirate marriage duty (Dt. 25:5-10). 11

The question obviously arises in relation to Calvin's categorizing as to how and why certain laws are assigned to his two sub-Decalogue categories. The point is, however, that he is refusing to allow that only the ten commandments themselves are of any relevance to Christians. The principles they express are also to be found in other laws which stand to a greater or lesser degree in relationship to them. Thus, while a modern state may differ greatly in its civil and political arrangements from the specific laws of Israel, that does not

${ }^{11}$ See 'Commentary on a Harmony of the Last Four Books of Moses' (1563) in Calvin Translation Society 3, pp. 111-179. 
matter, provided the modern laws serve the same purpose and safeguard the same basic principles. What matters is that the general equity which characterizes Israel's civil law should be preserved even if the literal form no longer is binding. If the essential principle of the Decalogue commandment is taken seriously, then matters of practical justice, fair treatment of the poor, protection of boundaries, etc., will fall into place with appropriate legislation, just as they did in Israel.12 To this extent, then, Calvin took the authority of the Old Testament law very seriously, and sought to show its relevance from a wider perspective than just the ten commandments. He was not, however, a 'theonomist' in the latter day sense of seeking to apply the whole Old Testament law as it stands to postbiblical societies. The modern Theonomist movement, since it stands closest to the Reformed theological worldview, often claims Calvin as patron saint. But there is no doubt that he would not have endorsed its assertion of literal application of Old Testament law in modern society, since he explicitly distinguished between permanent moral or natural law and temporary political laws. 13

\section{The Anabaptists}

The radical wing of the Reformation produced a remarkable variety of writings-remarkable in view of the pressures and prejudice they faced. It is harder to make general classifications of their position on a given subject than one can do for a single Reformer, like Luther or Calvin, but there are some significant common features. On the matter of biblical interpretation and the specific use of the Old Testament, we can point to certain areas of broad agreement between the Anabaptists and the mainline Reformers before identifying key areas of disagreement. 14

12See further D.F. Wright's discussion in 'Ethical Use', and also in 'Calvin's Pentateuchal Criticism: Equity, Hardness of Heart and Divine Accommodation in the Mosaic Harmony Commentary', Calvin Theological Journal 21 (1986) 33-50.

${ }^{13} \mathrm{~W}$. Robert Godfrey provides a helpful critique, from within the Reformed tradition itself, of the Theonomists' claim to Calvin, pointing out significant differences of approach and exegesis, in 'Calvin and Theonomy', W.S. Barker and W.R. Godfrey (edd.) Theonomy: A Reformed Critique (Grand Rapids, Academie Zondervan 1990) 299-312.

${ }^{14} \mathrm{~A}$ most helpful and illuminating collection of essays on Anabaptist biblical hermeneutics is provided by Willard Swartley (ed.), Essays on 
The Anabaptists were in full agreement with the other Reformers that the Bible was the authoritative word of God; that it could be understood clearly by the common person; that interpretation was to be free from bondage to ecclesiastical tradition; that special hermeneutical techniques were necessary to elucidate certain difficulties; and that in the end the Bible was meant to be obeyed. However, disagreement focussed on three major matters.

i) The scope of biblical relevance. The question was whether the Bible as a whole was to be applied to public, civil life or whether the New Testament applied to Christian personal behaviour only. The Reformers' position generally was that the Old Testament law could be related to civil affairs (thus permitting Old Testament sanctions and penalties in judicial and military matters), whereas the teachings of Christ were essentially for personal relationships between Christians. The Anabaptists asserted that the rule of Christ should govern the whole of life, including civil life also.

ii) The nature of the church and its relation to the state. The mainline Reformers are sometimes called 'magisterial' because of their conviction that the church and state were bound together in the purposes of God, and that the reformation of the church was part of the responsibility of the civil magistrate. Though they advocated different patterns of how that relationship should work, they were commonly committed to a broadly theocratic understanding of 'Christendom'. The Anabaptists, on the other hand, regarded the church as the separated and gathered community of true believers, clearly and visibly distinct from all secular institutions and certainly not part of the state. They rejected the 'Christendom' notion, and along with it the theocratic presuppositions derived from the Old Testament. The church was precisely not a nation state like Israel in the Old Testament, and therefore should not behave as if she were. This distinction is seen in two fundamental Anabaptist convictions:

a) Baptism. For the Reformers, infant baptism was part of Christian citizenship in a Christian state, and was justified partly through affirming its equivalence to Old Testament circumcision. To refuse it, or deny its validity by 're-baptism',

Biblical Interpretation: Anabaptist-Mennonite Perspectives, (Elkhart Indiana, Institute of Mennonite Studies 1984). 
was, in the religio-political context of 16th century Europe, tantamount to sedition or rebellion against the foundations of the state itself. For the Anabaptists, baptism is clearly commanded in the New Testament only for believers, has nothing to do with citizenship, and therefore the Old Testament was irrelevant to the question. The strength of Anabaptist conviction on this matter, coupled with the intense heat and severe cost of the controversy, probably led to a sharper devaluation of the Old Testament than would have been intended otherwise. That is, if the mainline Protestants justified infant baptism on Old Testament grounds, and then ruthlessly persecuted and slew Anabaptists for rejecting it (justifying the action again on Old Testament grounds), it is hardly surprising to find the Anabaptist counter-polemic seeking to undermine the Old Testament foundations of their enemies' position.

b) Pacifism. The Reformers argued that since civil authority was appointed by God, Christians were bound to obedience, which included bearing arms on behalf of the state in war. Again, the Old Testament was widely used in support of the legitimacy of war in certain circumstances. The major tradition of the Anabaptists (there were some groups who took an opposite and extreme view) took Jesus' teaching on nonviolence with total seriousness and therefore argued that Christians could not participate in violence or war. Again, since this was an issue that was so dear to them and so anathema to their opponents, it affected the hermeneutical argument. In order to high-light Christ's non-violence they had to put the Old Testament and its wars in the shadowseither by careful relativizing in relation to Christ, or by a less careful rejection of its authority which led in some cases to the charge of Marcionism.

So it can be seen that, in the Reformation era, to a considerable degree the question of the ethical authority and use of the Old Testament was affected by the prior question of ecclesiology, particularly in relation to the state. It would be possible to point to a comparable dynamic today. The extent to which Christian groups are prepared to use the Old Testament at all, or, if they are, the use to which they put it, is certainly partly affected by how they understand the nature of the church and its role in society in general. 
It is also interesting to note that the Anabaptist relegation of the Old Testament was partly a reaction to what they perceived as the continuing legalism and 'erastianism' (using the term anachronistically) of the mainline Protestant movement. This was also true, though in a very different ecclesiastical climate, of the origins of Dispensationalism, as we shall see in Part II.

iii) The absolute priority of obedience to Christ. This could probably be regarded as the guiding principle of Anabaptism in many respects. Christianity was a personal, spiritual experience of salvation through Jesus and thereafter of simple committed discipleship. What he said must be done. This could sometimes lead to a new kind of literalism and legalism of its own, but it certainly meant that the Old Testament was decidedly secondary to the New in moral priority. (Again, there were exceptions, such as Thomas Muntzer and Jan of Leyden, who resorted to Old Testament apocalypticism as justification for violence and other excesses). Sometimes this led to virtual Marcionism, and indeed, when coupled with claims for direct contemporary revelations of the Spirit, could lead to the abandoning of the New Testament as well among some on the radical spiritualist wing of the movement. But among the more careful and significant exegetes and leaders, it was still the position that the advent of Christ and the New Testament relativized the Old.

Menno Simons, an Anabaptist leader with the most enduring legacy, held the Old Testament in high regard, but believed that Christ enables Christians to go far beyond it.

According to Menno, Jesus Christ really did bring something new. The Old Covenant was displaced by the radical newness of Christ's kingdom. The mainline reformers stressed the continuity of the two testaments; for them there was really only one covenant in two dispensations. This principle enabled them to justify infant baptism by analogy to its Old Testament counterpart, circumcision. They also found in the Old Testament a pattern for church-state relationships. The Anabaptists denied the legitimacy of this appeal to the Old Testament by pointing to the normative status of the New Covenant. 15

${ }^{15} \mathrm{~T}$. George, Theology of the Reformers (Nashville, Broadman; Leicester, Apollos 1988) 276. 
Menno's superior evaluation of the New Testament was but the corollary of his basic affirmation-the centrality of Jesus Christ. . When Christ came he fulfilled the Law and enabled man to 'realize' fully what God wanted of him. Menno says that men can now go beyond the Old Testament Law, for they are directed to Christ. Moses served his day, now Christ has given a new commandment. . .Menno was fully aware of the ethical issues which stemmed from his theological concerns. His statements about warfare and the use of the sword grew out of his position of seeing the difference between the Old and New Testaments. Any vindictive approach to a person is ruled out because the New Testament forbids revenge, and the law of love must motivate the believer. Christ's command is too clear to be ignored, and wherever the Old Testament stipulations are not in accord with the teachings of Jesus and the apostles they must give way. ${ }^{16}$

Menno, like some other Anabaptists (e.g. Pilgram Marpeck),17 insisted that the Old Testament was still part of the Christian scripture, and made extensive use of it for devotional and spiritual exhortation. But the overwhelming priority in moral authority was given to the New Testament.

These hermeneutical debates of the Reformation era over the ethical authority and use of the Old Testament are fascinatingly relevant and alive today, though thankfully shorn of the vitriol and bloodshed that accompanied them in the sixteenth century. Do we give the Old Testament equivalent moral authority to the new, or a relativized and secondary authority, or none at all? Does obedience to Christ endorse the Old Testament or relegate it?

\section{The Modern Period}

In the twentieth century the field of Old Testament ethics has been subject to the same uncertainties and introspection as the field of Old Testament theology. Scholars have turned to asking whether there is such a category and if so, by what methodology it can be identified and presented. This led

${ }^{16} \mathrm{H}$. Poettcker, 'Menno Simons Encounter with the Bible' in Swartley, op. cit., 62-76 (70f.).

${ }^{17}$ See W. Klassen, "The Relation of the Old and New Covenants in Pilgram Marpeck's Theology', in Swartley, op. cit. 91-105. Klassen asks whether Marpeck was a Marcionite and concludes that he was not. Though he stressed the discontinuity of the old and new covenants, he placed a high value on the devotional use of the Old Testament. 
to a dearth of substantial writing on the subject in midcentury, which is happily giving way to a more fruitful period in these last two decades.

In terms of our initial threefold classification, modern critical scholarship could be described as Antiochene by virtue of its desire to see the historical depth and perspective of the biblical writings, including not only the crucial difference between the testaments, but also the internal variety of historical, literary and religious traditions in the Old Testament itself. Attempts to present systematized or diachronically unified accounts of the subject matter have been criticized on much the same grounds as similar attempts in Old Testament theology, such as Eichrodt's. Indeed, Eichrodt's classic model for structuring Old Testament theology included a major section on the ethical teaching of the Old Testament as well.18 Hempel likewise, one of the few to write an Old Testament ethic in that era, while obviously fully aware of the historical-critical issues of biblical scholarship, sought to present an overview of what could be seen as Old Testament ethics as a whole. 19

Both these works are critiqued by J. Barton, who argues that, in contrast with the systematic, diachronic approach, we can only satisfactorily make progress in the discipline if we take into account all the sociological, chronological and traditio-critical depths and nuances of the material. ${ }^{20}$ We need to distinguish between what some Israelites believed and did at various times, what certain Old Testament authors and traditions held regarding what Israelites should believe or do, and what kinds of behaviour the Old Testament as a whole may be said to condemn or endorse. We cannot assume that our construction of the last of these would have coincided with popular ethics in Israel-in theory or practice-at any given

${ }^{18} \mathrm{~W}$. Eichrodt, Theology of the Old Testament, Vol. 2 (London, SCM 1967) 316-379.

${ }^{19} \mathrm{~J}$. Hempel, Das Ethos des Alten Testaments, BZAW 67, 1938, rev. ed. 1964.

20J. Barton, 'Understanding Old Testament Ethics', JSOT 9 (1978) 44-64; and 'Approaches to Ethics in the Old Testament', in J. Rogerson (ed.), Beginning Old Testament Study (London, SPCK 1984) 113-30. A similar critique with reflections on critical method in the field of OT ethics is found in $\mathrm{H}$. McKeating, 'Sanctions against adultery in ancient Israelite society, with some reflections on methodology in the study of OT ethics', JSOT 11 (1979) 57-72. 
time. Yet neither can we reduce Old Testament ethics merely to a descriptive history of Israel's behaviour, any more than Old Testament theology can be reduced to a history of Israel's religion. We can discern an 'ethos' or 'general drift' of the moral worldview of ancient Israel. There was a pattern of life lived in the presence of God and pleasing to him which has a number of constant factors through the whole period. "The (Old Testament) law affords an insight into the contours of God's own ideal will for his people and for all mankind'.21 Barton lists at least three fundamental elements in this 'ethos': i) obedience to the divine will; ii) conformity to a pattern of natural order; iii) imitation of God.

J. Rogerson also relates Old Testament morality to a natural order. ${ }^{22} \mathrm{He}$ finds much in common between Israelite law and the laws and other moral texts of contemporary Ancient Near Eastern societies, and thus sees the moral norms of Israel as reflecting that natural morality of the time. This is not the same as 'natural law' in the dogmatic sense, since it is clearly historically conditioned. But the modern Christian (or non-Christian) can still learn from these ancient texts when we observe their moral consensus and weigh it up in its historical context. There are principles, but they are not timeless or unique to Israel. However, if we are to take the Old Testament's moral demands seriously as Christians, we have to do so in the light of the Old Testament's imperatives of redemption. We are reminded by it of our total dependence on God, our constant need for his grace, and our need for the vision of his kingdom which the Bible alone supplies.

Another critic of the attempt to derive absolute moral norms from the Old Testament material is R.R. Wilson. ${ }^{23} \mathrm{He}$ points out how the narratives of the Deuteronomic historians appear quite inconsistent in applying Torah norms to some of the central characters in Israel's history. So if Pentateuchal laws did not exclusively govern the ethical evaluation even of

${ }^{21}$ Idem, 'Approaches', 128.

${ }^{22} \mathrm{~J}$.W. Rogerson, 'The Old Testament and social and moral questions', The Modern Churchman 25 (1982) 28-35.

${ }^{23}$ R.R. Wilson, 'Approaches to Old Testament Ethics', in G.M. Tucker, D.L. Petersen and R.R. Wilson (edd.), Canon, Theology and Old Testament Interpretation: Essays in Honor of Brevard S. Childs (Philadelphia, Fortress 1988) 62-74. 
biblical authors, why should they be considered binding on us in any direct way?

R.E. Clements also recognizes the historically contextual limits on the ethical material of the Old Testament and observes how even phrases which have passed into the fundamentals of the Christian ethical tradition (such as 'Love your neighbour as yourself') come in contexts which are 'occasional' and sometimes syntactically incidental. ${ }^{24}$ It is questionable, in his view, whether the Old Testament gives us, in its own words and by its own intention, any timeless moral principles. Nevertheless, Clements is impressed with the breadth and durability of Old Testament moral insights. 'Overall, the Old Testament literature appears to be feeling its way towards the formulation of universal principles of morality' (p.17). Certain moral priorities and demands are so repeatedly apparent that they achieve a "sense of "primacy" as regards importance (which) readily lends itself to a sense of "principle", as regards universal applicability' (p.17). Clements also observes how the long history of Israel in the Old Testament period gave ample opportunity for the fundamental insights and values of their society to be tested and refined in an amazing variety of historical situations. Since Israel had to adapt and yet preserve essentials, the norms and values they expressed through law, prophecy, narrative, worship and wisdom, likewise manifest that quality of adaptability.

The Old Testament has provided a system of tora-instruction, which has proved to be remarkably adaptable to a vast range of human social and political systems. Societies of dramatically different economic, political and cultural types have found within the Old Testament a richly viable source of social and moral teaching (p. 22).

Birch and Rasmussen take a somewhat different approach and argue that the Old Testament, while it cannot be prescriptive or normative for the Christian, can help to shape the Christian's moral identity and character. ${ }^{25}$ In more recent writing, Birch has emphasised particularly the power of biblical

${ }^{24}$ R.E. Clements, 'Christian Ethics and the Old Testament', The Modern Churchman 26 (1984) 13-26.

${ }^{25}$ B.C. Birch and L.L. Rasmussen, Bible and Ethics in the Christian Life (Minneapolis, Augsburg, 1976). 
narrative to this end.26 The Old Testament narratives have moral power in exposing reality, shattering or transforming worldviews and challenging the reader to response. They therefore have to be read as wholes within their canonical context, and not just by the methods of historical criticism. The canonical approach also underlies Birch's most recent book, 27 in which he seeks to apply the broad themes of the Old Testament, arranged in the historical pattern of the canon, to the ethical task facing the Christian and the church in the modern world. This is welcome, even though it is not finally clear what actual moral authority the Old Testament bears for the Christian. It has power, but not authority. 'Authority is not a property inherent in the Bible itself. . .it is a recognition of the Christian community over the centuries of experience that the scripture is a source of empowerment for its moral life in the world' (p. 34).

One of the most prolific advocates of unleashing the ethical power and challenge of the Old Testament has been Walter Brueggemann.28 His handling of the text has an almost 'kerygmatic' force as he constantly strives to see how the great themes of biblical theology address modern issues. He finds in the narratives of Israel, in the message of the prophets, in the passion for justice on the land etc., material that exposes the dynamics of human relationships-personal, social and international-and calls for new ways of bringing God's word into a veritably 'missionary' engagement with contemporary realities.

The goal of bringing the Old Testament texts to bear on contemporary issues, however, can become overlaid with a heavy dose of ideology. N.K. Gottwald's overtly Marxist reading of the Hebrew Bible is a case in point, though other examples from various liberationist or advocacy stances could

26B.C. Birch, 'Old Testament Narrative and Moral Address', in Tucker, Petersen and Wilson, op. cit., 75-91.

27B.C. Birch, Let Justice Roll Down: The Old Testament, Ethics and the Christian Life (Louisville, Westminster John Knox 1991).

${ }^{28}$ It is almost impossible to select from Brueggemann's enormous output. Among his most stimulating books, however, must be included, The Land: Place as Gift, Promise and Challenge in Biblical Faith (Philadelphia, Fortress SPCK 1978), and, The Prophetic Imagination (Fortress 1978). 
be given.29 Gottwald, perhaps the best known figure in the recent upsurge of sociological study of the Old Testament, sees ethical relevance in the Old Testament, not in the sense of a revelation of God with ethical norms inherent in it, but rather in its portrayal of the historical struggle of Israel. According to Gottwald's sociological explanation, Israel is a remarkable historical case study of a people committed to a great experiment in social freedom, equality and justice, an experiment which generated a supporting and sanctioning religionmono-Yahwism. Any authority it may have lies in the realm of historical precedent and contemporary challenge, not in the spiritualising idealism of claiming Yahweh as our own God.30 Gottwald's sociological positivism and critical methodology will be unacceptable to those committed to any view of divine authority in Scripture, and have not gone unchallenged in the wider world of critical scholarship also. But in my view he has made the significant contribution to Old Testament ethics of establishing the importance of studying Israel as a total social organism, so that we no longer simply try to quarry out ethical 'gems' from isolated texts, but rather see the relevance of all that Israel tried to be and achieve in their historical context. ${ }^{31}$

In seeking to evaluate the recent work in the field by scholars such as those briefly sampled above, one can begin with several points of positive appreciation. First of all, there is no doubt that the emphasis on history and context in studying the moral teaching of the Old Testament keeps us rooted in reality. There are many helpful perspectives on Israel's actual response to the ethical issues and dilemmas that bristled in her own world. As we see how they articulated an understanding of themselves in relation to God and the world around them, and how they so acutely perceived the tension between the ideals of their faith and the realities of their history (in narrative, prophecy and worship), we are given an abundance of

${ }^{29}$ It would extend this article inordinately to include any adequate discussion of the use of the OT in Liberation Theology (of many varieties) or in Feminist writings of recent years. I am conscious of this gap, which would however, require a separate article to fill.

${ }^{30}$ N.K. Gottwald, The Tribes of Yahweh: A Sociology of the Religion of Liberated Israel 1250-1050 BCE (London, SCM 1980).

31I have summarised and critiqued Gottwald's approach and assessed its contribution to biblical ethics in my 'The Ethical Relevance of Israel as a Society', Transformation 1.4 (1984) 11-21. 
resources in the task of transferring their ethical values and priorities out of their cultural context and into our own. This is not, of course, an obvious or easy transferance. But at least the historical and sociological depth of recent study enables us to understand much more clearly what it is we are seeking to make relevant. It also warns us of the danger of too quickly moving from a possibly incidental feature of the Old Testament text to an alleged universal principle of Christian ethics.

Secondly, there is a much deeper understanding of how literary texts, of widely differing genres actually function in shaping our ethics. Newer literary critical approaches have alerted us to the importance of reader response. Though not without its problems also, as we shall see in Part II, this new emphasis has made us more aware of the need to be more nuanced in what we mean by 'moral authority' in a given text. If it can be difficult to express precisely what the authority of an Old Testament law is for Christians, when at least the text is in the imperative mood to start with, how much more difficult is it to clarify how a narrative functions authoritatively, or a poem.

But that difficulty is precisely something which is not adequately tackled in recent critical scholarship, in my view. As mentioned above, it is possible to talk about the power of the text without really coming to grips with the question of its authority. The question is whether the Old Testament carries, for Christians, an authority which requires us to hear and respond to its texts as the word of God. Perhaps Clements comes close to that when he suggests that the Old Testament's ethical development tends towards a clear affirmation of the 'autonomy of the moral realm', but that in itself needs unpacking! So the challenge of the Old Testament texts is certainly there in recent critical scholarship, and can even be very eloquently expressed. Yet it seems somehow ungrounded in any view of prescriptive normativity. If the Old Testament text is not telling us what we ought to do directly, is there any way in which it is telling us what to do at all? And how can we find that out and articulate it?

In Part II we shall examine some contemporary evangelical attempts to answer these questions, in volume $\mathbf{4 3 . 2}$ (November, 1992) 